\title{
Enhancing Chemical Interaction of Polysulfide and Carbon through Synergetic Nitrogen and Phosphorus Doping
}

\author{
Junhua Song ${ }^{1}$, Jianming Zheng ${ }^{2}$, Renqin Zhang ${ }^{3}$, Shaofang $\mathrm{Fu}^{1}$, Chengzhou Zhu ${ }^{1}$, Shuo
}

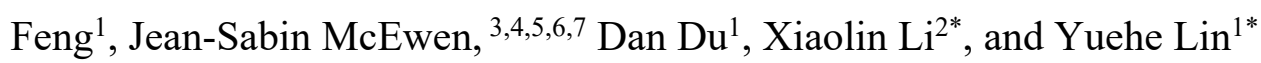

1. School of Mechanical and Materials Engineering, Washington State University, Pullman, Washington 99164, United States

2. Energy and Environmental Directory, Pacific Northwest National Laboratory, Richland, Washington 99354, United States

3. The Gene and Linda Voiland School of Chemical Engineering and Bioengineering, Washington State University, Pullman, Washington 99164, United States

4. Department of Physics and Astronomy, Washington State University, Pullman, WA 99164

5. Department of Chemistry, Washington State University, Pullman, WA 99164

6. Department of Biological Systems Engineering, Washington State University, Pullman, Washington 99164, USA

7. Institute for Integrated Catalysis, Pacific Northwest National Laboratory, Richland, WA, 99352

*E-mail: xiaolin.li@pnnl.gov; yuehe.lin@wsu.edu

Number of pages: 9

Number of figures: 9

Number of tables: 5 


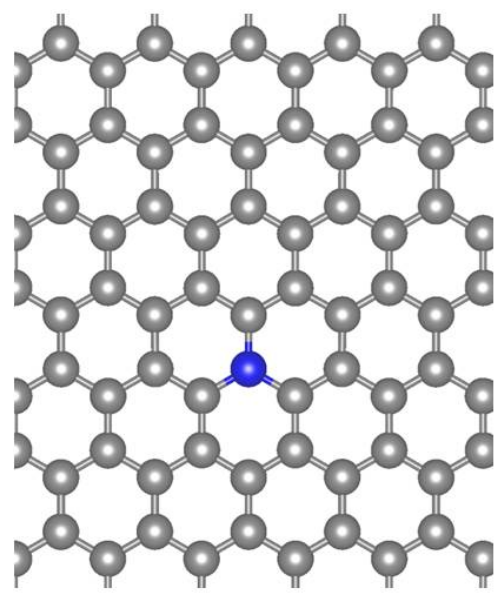

(a) Graphitic N

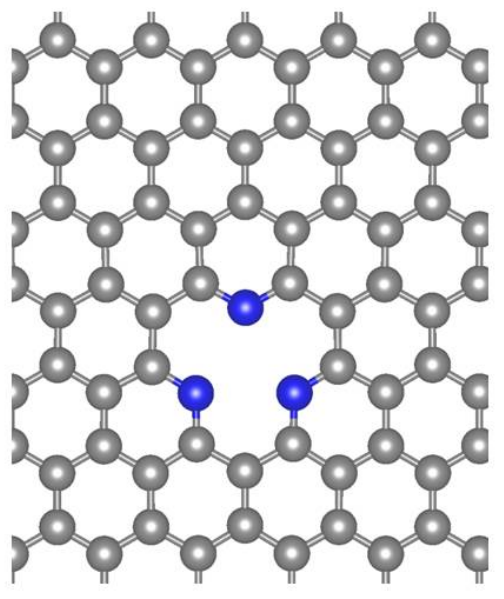

(b) Pyridinic $\mathrm{N}$

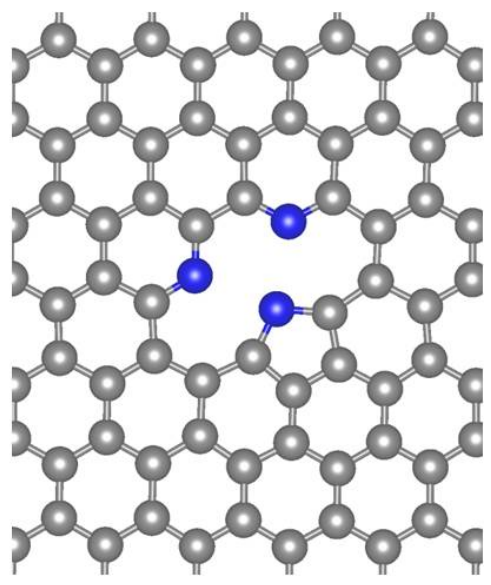

(c) Pyrrolic N

Figure S1. Schematic illustration of nitrogen atom located at (a) graphitic, (b) pyridinic and (c) pyrrolic positions in carbon sheet. The grey and blue spheres are carbon and nitrogen atoms, respectively.

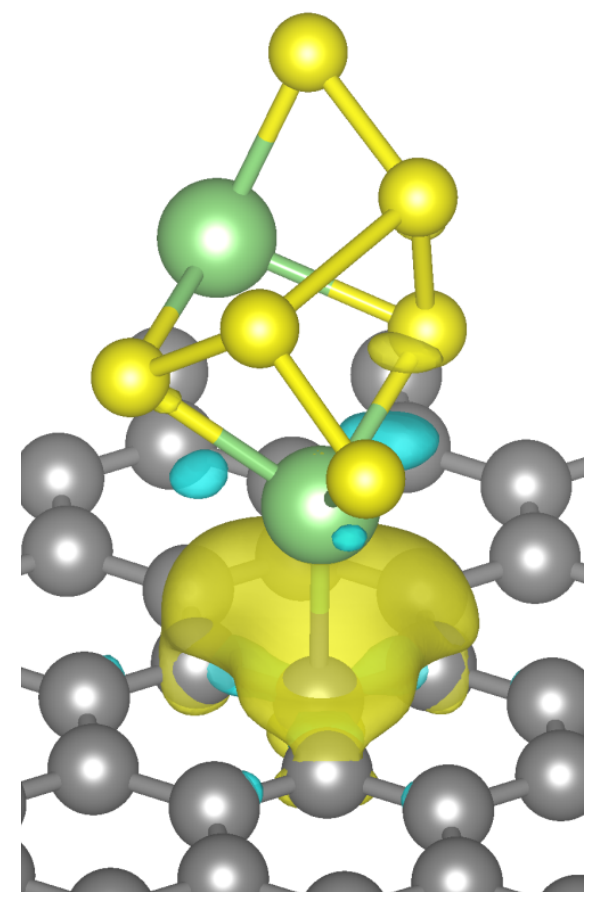

Figure S2. Illustration of structure of $\mathrm{Li}_{2} \mathrm{~S}_{6}$ adsorbed on carbon sheet. The green and yellow spheres are $\mathrm{Li}$ and $\mathrm{S}$, respectively. The isosurfaces $\left(0.005 e \mathrm{bohr}^{-3}\right)$ of charge density difference are displayed in the form of blue and yellow clouds, indicating the regions of electron loss and gain, respectively. 
Table S1. Energy difference of phosphorus at difference location in pyridinic N doped carbon as shown in Figure 1B and C.

\begin{tabular}{|c|c|}
\hline Position & Energy difference (eV) \\
\hline $\mathbf{1}$ & 0.56 \\
\hline $\mathbf{2}$ & 0.00 \\
\hline $\mathbf{3}$ & 0.01 \\
\hline $\mathbf{4}$ & 0.12 \\
\hline $\mathbf{5}$ & 0.15 \\
\hline $\mathbf{6}$ & 0.10 \\
\hline
\end{tabular}

Table S2. Adsorption energies of NC and NPC against various polysulfide species.

\begin{tabular}{|c|c|c|c|}
\hline Position & $\mathbf{C}(\mathbf{e V})$ & $\mathbf{N C}(\mathbf{e V})$ & $\mathbf{N P C}(\mathbf{e V})$ \\
\hline $\mathbf{L i}_{\mathbf{2}} \mathbf{S}_{\mathbf{2}}$ & 0.79 & 1.25 & 1.68 \\
\hline $\mathbf{L i}_{\mathbf{2}} \mathbf{S}_{\mathbf{4}}$ & 0.57 & 1.14 & 1.32 \\
\hline $\mathbf{L i}_{\mathbf{2}} \mathbf{S}_{\mathbf{6}}$ & 0.68 & 1.24 & 1.47 \\
\hline $\mathbf{L i}_{\mathbf{2}} \mathbf{S}_{\mathbf{8}}$ & 0.78 & 1.36 & 1.44 \\
\hline
\end{tabular}




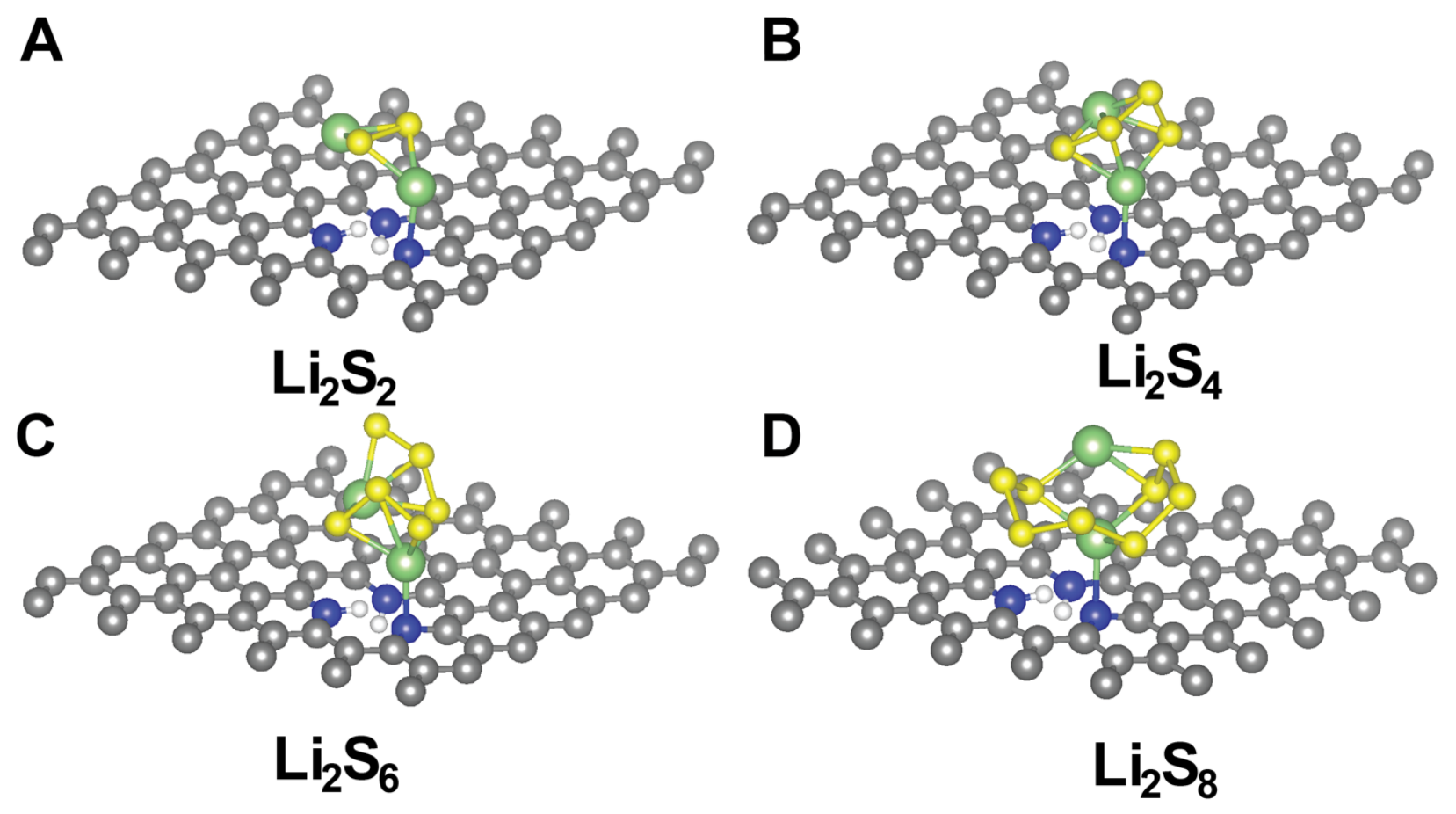

Figure S3. The structural configurations of various lithium polysulfide species, Li2S2 (A), Li2S4 (B), Li2S6 (C) and Li2S8 (D) absorbed on the $\mathrm{NC}$ sheet. The figure legend is that given in Figure $\mathrm{S} 1$ and $\mathrm{S} 2$.
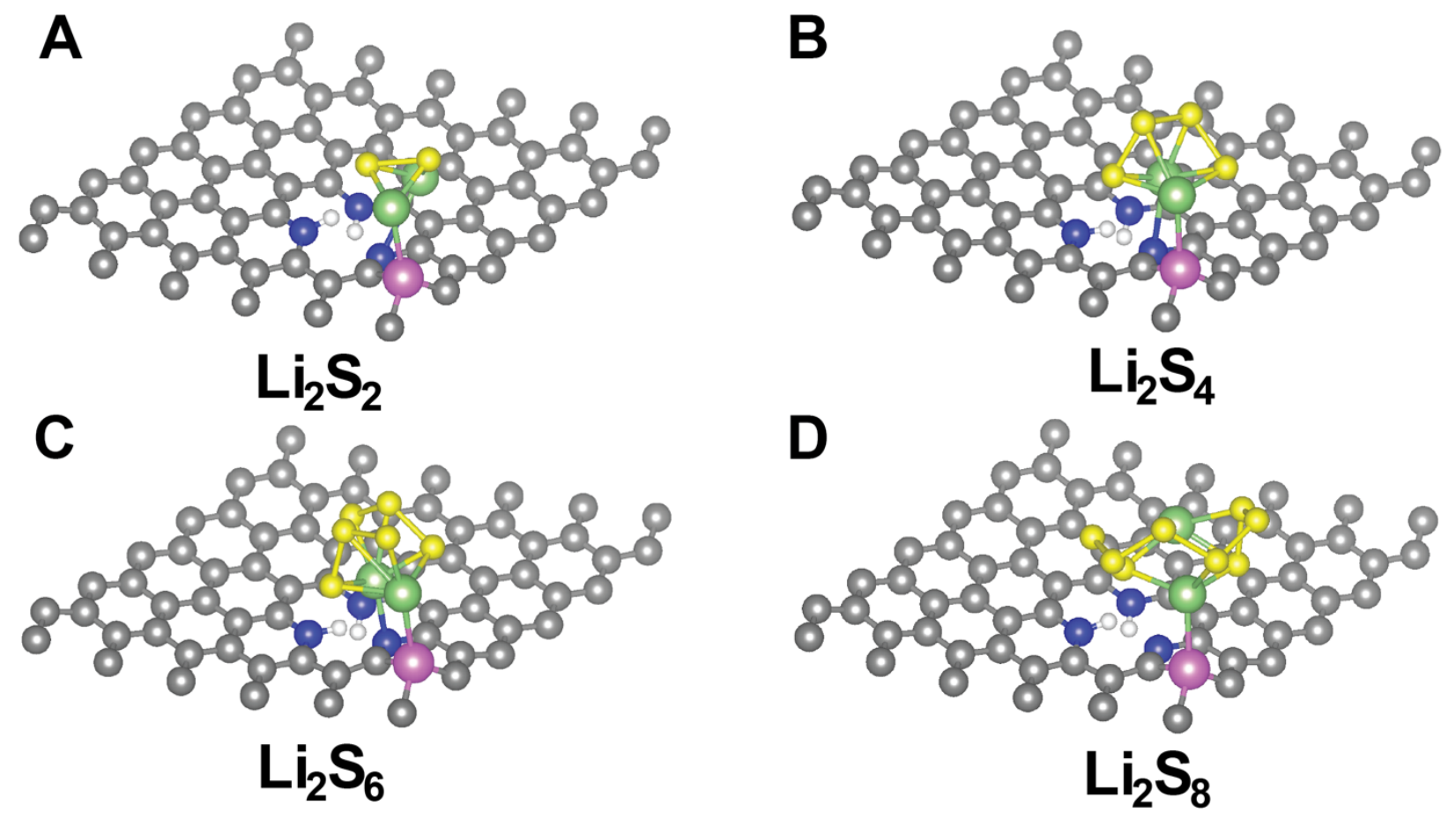

Figure S4. The structural configurations of various lithium polysulfide species, Li2S2 (A), Li2S4 (B), Li2S6 (C) and Li2S8 (D) absorbed on the NPC sheet. The purple sphere is a P atom and the 
legend for the other atoms are as given in Figure S1 and S2.

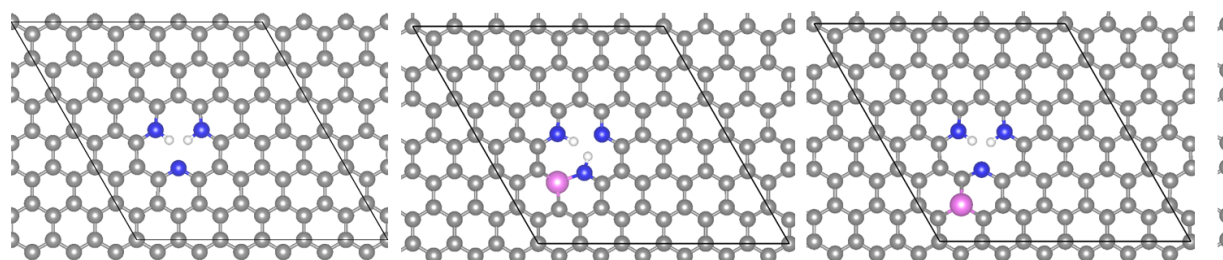

pyridinic $\mathrm{N}$

$0.00 \mathrm{eV}$ site 1

$0.90 \mathrm{eV}$

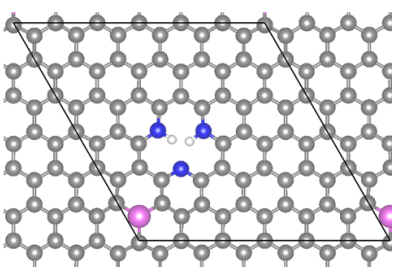

site 3

$-0.48 \mathrm{eV}$

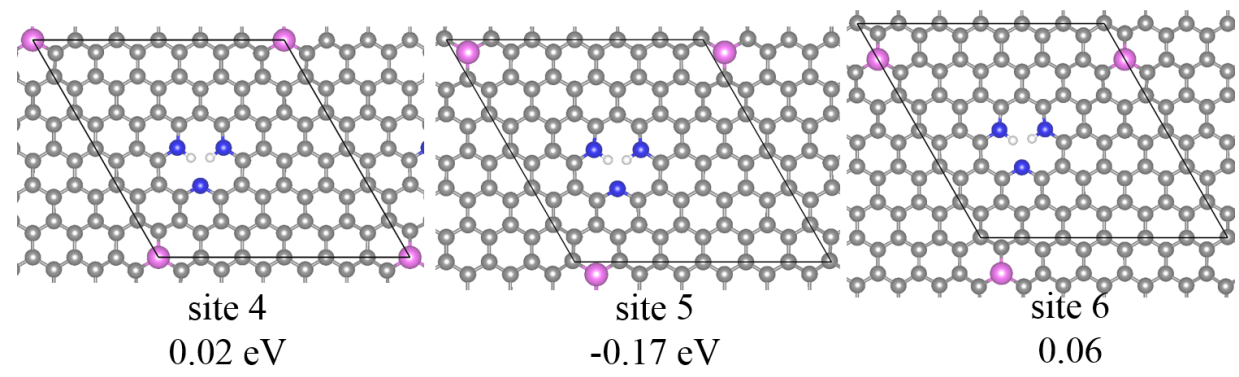

Figure S5. Effect of co-doping P on the N 1s core-level binding energy shift with respect to the pyridinic $\mathrm{N}$. The values of $\mathrm{N} 1 \mathrm{~s}$ core-level binding energy shifts are displayed in each configuration. The following paragraph provides detail information to calculate the core-level binding energy. The unit cell that is used in the calculations are displayed.

The core-level binding energy is defined as the energy to remove a core electron from an atom, and can serve as a bridge to connect experimental and computational results. ${ }^{1,2}$ To correlate the DFT calculations with our experimental results in Figure 2, we calculated the $\mathrm{N}$ 1s core level binding energy shifts between the various co-doping configurations with respect to the pyridinic $\mathrm{N}$ structure for the $\mathrm{N}$ atom without a $\mathrm{H}$ atom termination by using the so-called final state approximation. ${ }^{1 \mathrm{a}}$ The $\mathrm{N}$ 1s core level binding energy shift $E_{C L S}$ is defined as:

$E_{C L S}=\left[E_{\mathrm{P}_{i} \text { on N-Doped C }}\left(n_{c}-1\right)-\mathrm{E}_{\mathrm{P}_{i} \text { on N-Doped C }}\left(n_{c}\right)\right]-\left[E_{\text {Pyridinic N }}\left(n_{c}-1\right)-E_{\text {Pyridinic N }}\left(n_{c}\right)\right]$

where $n_{c}$ is the total number of core electrons in the system, $E_{\mathrm{P}_{i} \text { on N-Doped C }}\left(n_{c}-1\right)$ is the total energy of the $\mathrm{N}$ and $\mathrm{P}$ co-doped graphene model with the $\mathrm{P}$ location of $i$ ( $i=1$ to 6 , as shown in Figure S5) and with a single core electron removed from the $\mathrm{N} 1 \mathrm{~s}$ state from the $\mathrm{N}$ atom that does not have a $\mathrm{H}$ atom termination. $\mathrm{E}_{\mathrm{P}_{i} \text { on N-Doped } \mathrm{C}}\left(n_{c}\right)$ is the total energy of the $\mathrm{N}$ and $\mathrm{P}$ co-doped graphene model 
with the P location of $i(i=1$ to 6 , as shown in Figure S5) and with all core electrons present in the system. $E_{\text {Pyridinic N }}\left(n_{c}-1\right)$ is the total energy of the N-doped graphene model with a single core electron removed from a $\mathrm{N} 1 \mathrm{~s}$ state from the $\mathrm{N}$ atom that does not have a $\mathrm{H}$ atom termination, and $E_{\text {Pyridinic N }}\left(n_{c}\right)$ is the total energy of the total energy of the N-doped graphene model with all core electrons present in the system.
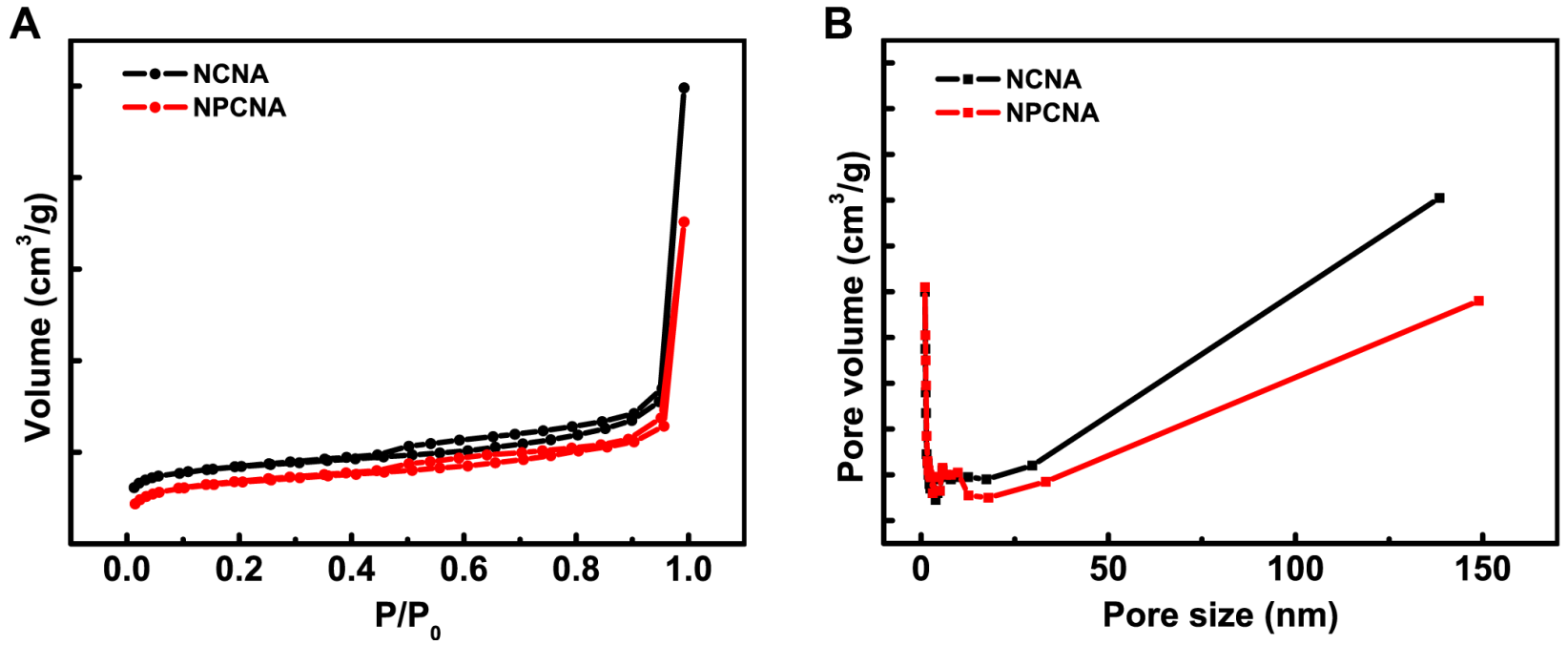

Figure S6. (A) Nitrogen adsorption isotherm of NCNA and NPCAN at 77k. (B) Pore size distribution of NCAN and NPCNA.

Table S3. Teller (BET) surface area, micropore surface area and pore volume of NCNA and NPCNA.

\begin{tabular}{|c|c|c|c|}
\hline Sample & $\begin{array}{c}\text { Surface area } \\
\left(\mathbf{m}^{\mathbf{2}} / \mathbf{g}\right)\end{array}$ & Micropore surface area $\left(\mathbf{m}^{\mathbf{2}} / \mathbf{g}\right)$ & $\begin{array}{c}\text { Pore volume } \\
\left(\mathbf{c m}^{\mathbf{3}} / \mathbf{g}\right)\end{array}$ \\
\hline NCNA & 1302 & 1056 & 1.1 \\
\hline NPCNA & 1441 & 1210 & 1.5 \\
\hline
\end{tabular}

Table S4. Atomic concentration of nitrogen and phosphorus in NCNA and NPCNA.

\begin{tabular}{|c|c|c|c|}
\hline Sample & Nitrogen (\%) & Phosphorus (\%) & Doping Level (\%) \\
\hline NCNA & 1.98 & - & 1.98 \\
\hline NPCNA & 0.91 & 0.12 & 1.03 \\
\hline
\end{tabular}




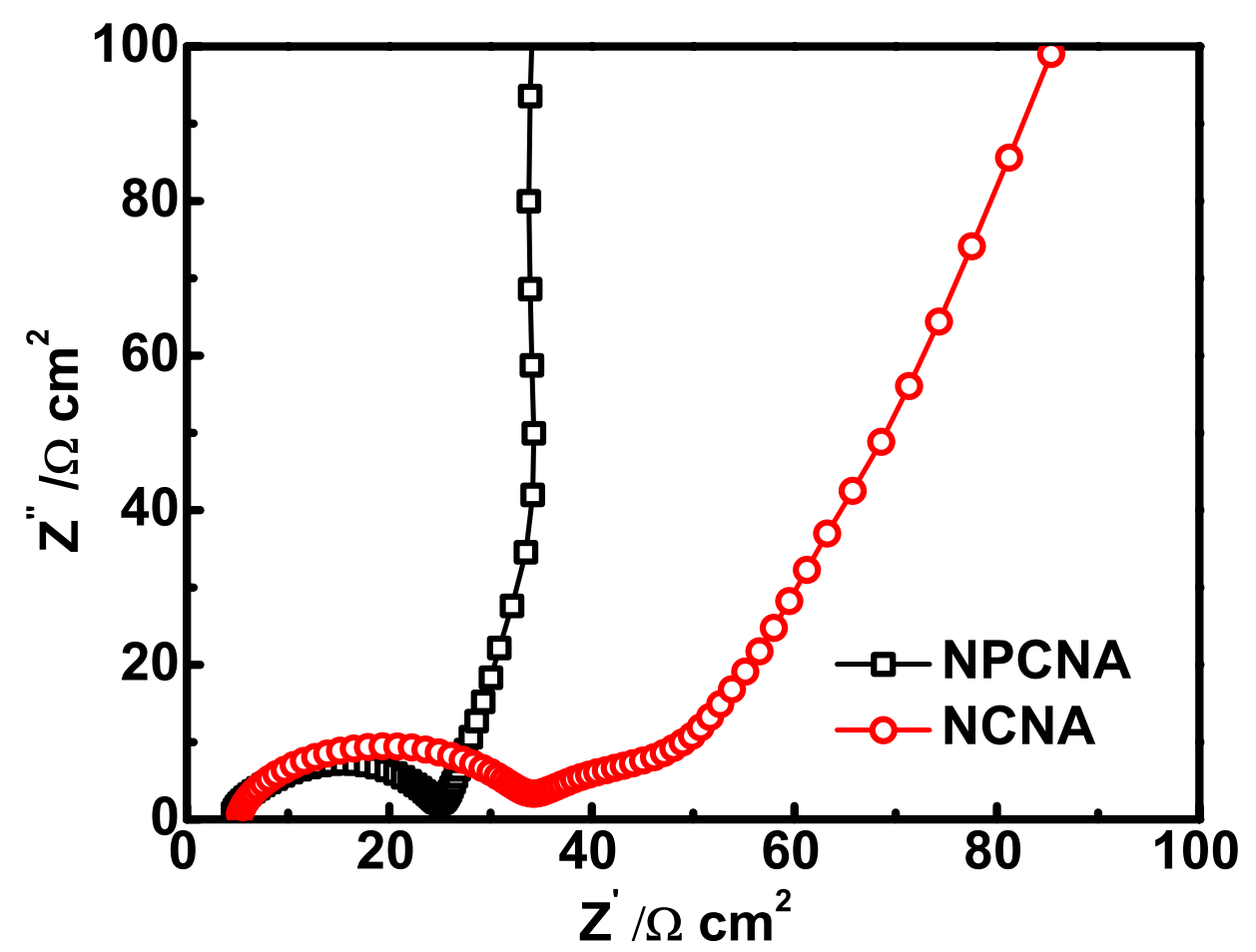

Figure S7. Electrochemical impedance spectroscopy (EIS) analysis of fresh NCNA and NPCAN cells.

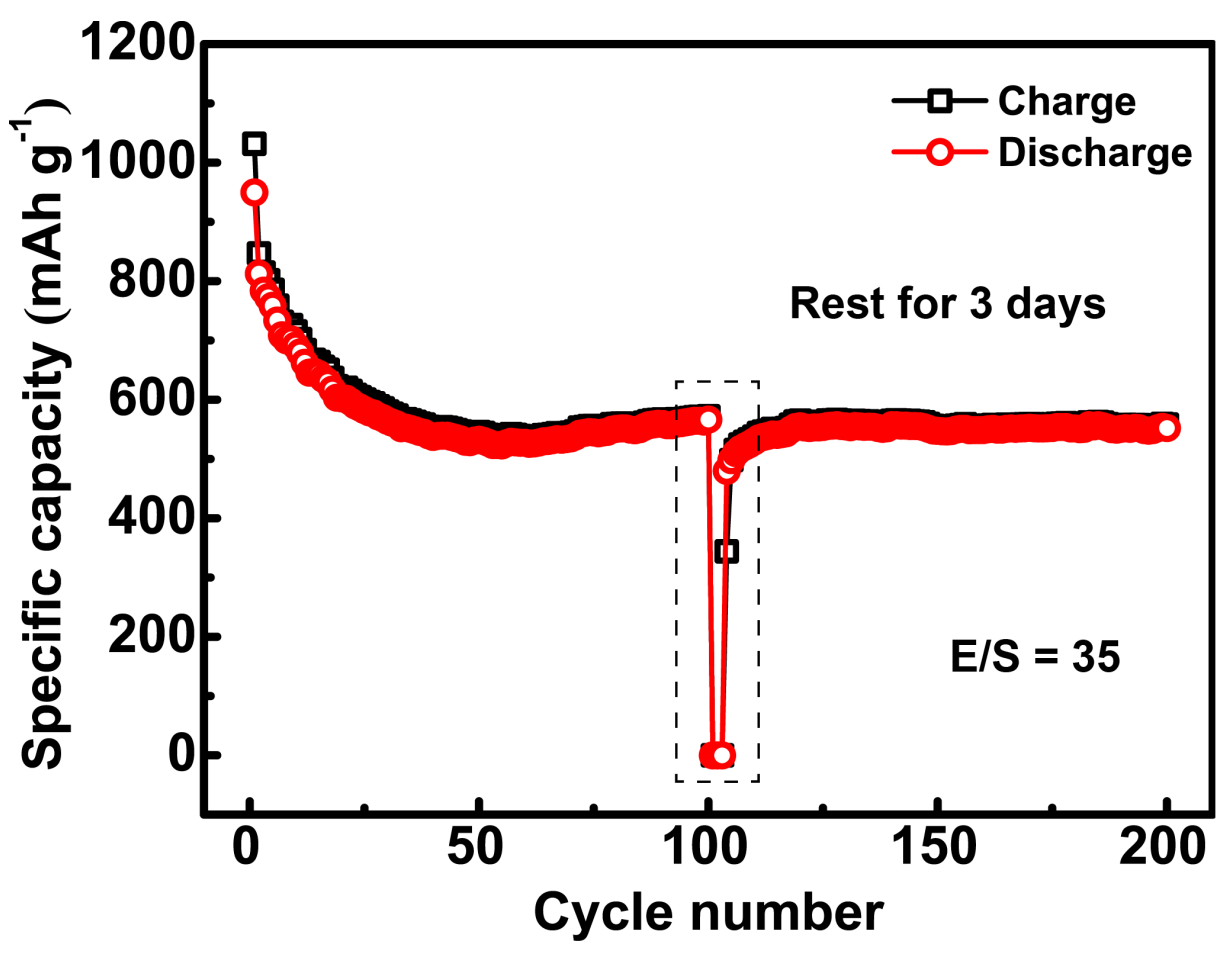

Figure S8. Cycling performance of NPCNA electrode with S/E ratio of $28 \mathrm{~g} \mathrm{~L}^{-1}$. The cycling was stopped for 3 days after 100 cycles and then restarted for another 100 cycles. 

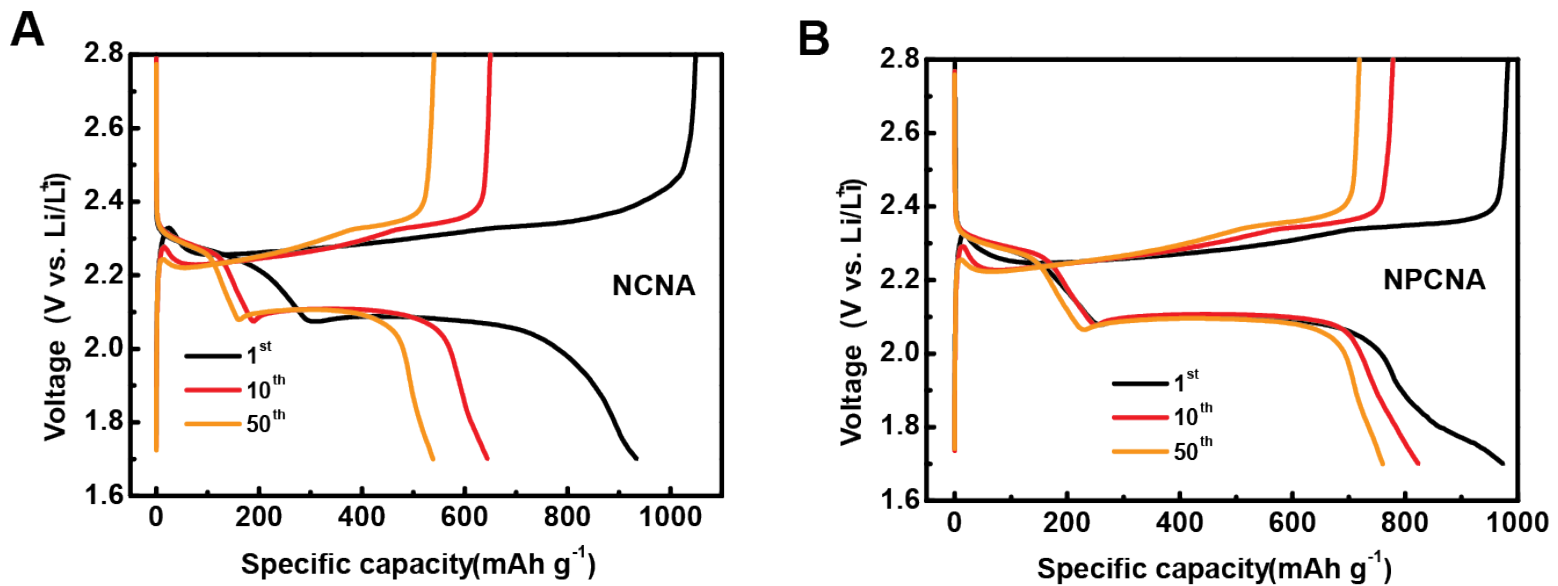

Figure S9. Charge-discharge curves of (A) NCNA (B) NPCNA derived from Figure 4A.

Table S5. Performance comparison of heteroatom doped carbon host structures.

\begin{tabular}{|c|c|c|}
\hline Material & \begin{tabular}{|l|} 
Performance \\
\end{tabular} & Reference \\
\hline P doped CNT & $\begin{array}{l}1106 \mathrm{mAh} \mathrm{g}^{-1}(0.1 \mathrm{C}), 77.8 \% \\
\text { retention }(100 \text { cycles, } 1 \mathrm{C})\end{array}$ & $\begin{array}{l}\text { Guo, Meng-qing, et al. New } \\
\text { Carbon } \quad \text { Materials } 31.3 \\
\text { (2016): 352-362. }\end{array}$ \\
\hline $\begin{array}{l}\mathrm{N}, \mathrm{S} \text { doped mesoporous } \\
\text { carbon }\end{array}$ & $\begin{array}{l}1120 \mathrm{mAh} \mathrm{g}^{-1} \quad(1 \mathrm{C}), \quad 77 \% \\
\text { retention }(250 \text { cycles, } 2 \mathrm{C})\end{array}$ & $\begin{array}{l}\text { Wu, Feng, et al. Scientific } \\
\text { reports } 5 \text { (2015): } 13340 .\end{array}$ \\
\hline $\mathrm{N}, \mathrm{P}$ doped carbon & $\begin{array}{l}1000 \mathrm{mAh} \mathrm{g}^{-1}(0.1 \mathrm{C}), 70 \% \\
\text { retention }(100 \text { cycles, } 0.1 \mathrm{C})\end{array}$ & $\begin{array}{l}\text { Zhang, Jun, et al. Advanced } \\
\text { Energy Materials } 7.14 \text { (2017): } \\
1602876 .\end{array}$ \\
\hline Boron doped carbon & $\begin{array}{l}1300 \mathrm{mAh} \mathrm{g} \mathrm{g}^{-1}(0.25 \mathrm{C}), 70 \% \\
\text { retention }(80 \text { cycles, } 0.1 \mathrm{C})\end{array}$ & $\begin{array}{l}\text { Yang, Chun-Peng, et al. ACS } \\
\text { applied materials \& } \\
\text { interfaces } 6.11 \text { (2014): 8789- } \\
8795 .\end{array}$ \\
\hline $\mathrm{N}$ doped 3D & $\begin{array}{l}1314 \mathrm{mAh} \mathrm{g}^{-1}(0.2 \mathrm{C}), 75 \% \\
\text { retention }(200 \text { cycles, } 0.5 \mathrm{C})\end{array}$ & $\begin{array}{l}\text { Ding, Yuan-Li, } \\
\text { al. Advanced } \\
\text { Materials } 26.7 \text { (2016): 1112- } \\
\text { 1119. }\end{array}$ \\
\hline $\mathrm{N}, \mathrm{P}$ doped porous carbon & $\begin{array}{l}1580 \mathrm{mAh} \mathrm{g}^{-1}(0.02 \mathrm{C}), 70 \% \\
\text { retention }(200 \text { cycles, } 1 \mathrm{C})\end{array}$ & $\begin{array}{l}\text { Ai, Wei, et al. Energy Storage } \\
\text { Materials } 6 \text { (2017): 112-118. }\end{array}$ \\
\hline $\mathrm{N}, \mathrm{P}$ doped 3D carbon & $\begin{array}{l}1446 \mathrm{mAh} \mathrm{g}^{-1}(0.1 \mathrm{C}), 86 \% \\
\text { retention }(400 \text { cycles, } 1 \mathrm{C})\end{array}$ & $\begin{array}{l}\text { Wu, Huali, et al. Journal of } \\
\text { Materials Chemistry A } 5.38\end{array}$ \\
\hline
\end{tabular}




\begin{tabular}{|l|l|l|}
\hline & & (2017): 20458-20472. \\
\hline Honeycomb N, P doped carbon & $\begin{array}{l}1387 \mathrm{mAh} \mathrm{g}^{-1} \quad(0.2 \mathrm{C}), 67 \% \\
\text { retention (200 cycles, 0.2C) }\end{array}$ & $\begin{array}{l}\text { Zeng, Pan, et al. Chemical } \\
\text { Engineering Journal 349 } \\
(2018): 327-337 .\end{array}$ \\
\hline $\begin{array}{l}\text { N,P doped carbon nanotube } \\
\text { aerogel (NPCNA) }\end{array}$ & $\begin{array}{l}987 \mathrm{mAh} \mathrm{g}^{-1} \quad(0.2 \mathrm{C}), 70 \% \\
\text { retention (450 cycle, 0.2C) }\end{array}$ & Our work \\
\hline
\end{tabular}

\section{References}

1. Köhler, L.; Kresse, G., Density functional study of $\mathrm{CO}$ on Rh(111). Phys. Rev. B 2004, 70 (16), 165405, DOI 10.1103/PhysRevB.70.165405.

2. Papp, C.; Fuhrmann, T.; Tränkenschuh, B.; Denecke, R.; Steinrück, H. P., Site selectivity of benzene adsorption on $\mathrm{Ni}(111)$ studied by high-resolution $\mathrm{x}$-ray photoelectron spectroscopy. Phys. Rev. B 2006, 73 (23), 235426, DOI 10.1103/PhysRevB.73.235426. 